\title{
History and Development of Islamic Banking Regulations in the National Legal System of Indonesia
}

\author{
Andrew Shandy Utama
}

\begin{abstract}
History and Development of Islamic Banking Regulations in the National Legal System of Indonesia. The economic crisis in 1998 caused a number of national banks to collapse. Strangely, such a great crisis turned out to have no effect on the syariah banking world. Even as the crisis passed, a number of new Shari'ah banks emerged, such as Bank Syariah Mandiri, Bank Permata Syariah, Bank Mega Syariah, Bank Rakyat Indonesia Syariah, Bank Syariah Bukopin, and so forth. This study examines the development of Islamic banking in Indonesia. The aim is to find out factors driving and inhibiting the growth of these banking institutions. This study uses normative legal research methods. The results shows that the Islamic banking institutions could grow and develop rapidly due to two factors: internal and external factors. On the internal side, the Shari'ah bank has a usury management system that makes it able to withstand the economic crisis; while from the external side it has to do with government support, especially after the issuance of Law Number 21 of 2008.
\end{abstract}

Keywords: Islamic banking, history of Islamic banking, Indonesia

\begin{abstract}
Abstrak: Sejarab Perkembangan Regulasi Perbankan Syariab dalam Sistem Hukum Nasional Indonesia. Krisis ekonomi pada tahun 1998 menyebabkan sejumlah bank nasional runtuh. Anehnya, krisis yang begitu besar ternyata tidak berdampak pada dunia perbankan syari'ah. Bahkan ketika krisis berlalu, sejumlah bank syariah baru muncul, seperti Bank Syariah Mandiri, Bank Permata Syariah, Bank Mega Syariah, Bank Rakyat Indonesia Syariah, Bank Syariah Bukopin, dan sebagainya. Studi ini meneliti perkembangan perbankan syariah di Indonesia. Tujuannya adalah untuk mengetahui faktor-faktor yang mendorong dan menghambat pertumbuhan lembaga-lembaga perbankan ini. Penelitian ini menggunakan metode penelitian hukum normatif. Hasil penelitian menunjukkan bahwa lembaga perbankan syariah dapat tumbuh dan berkembang pesat karena dua faktor: faktor internal dan eksternal. Di sisi internal, bank syariah memiliki sistem manajemen riba yang membuatnya mampu menahan krisis ekonomi; sedangkan dari sisi eksternal berkaitan dengan dukungan pemerintah, terutama setelah dikeluarkannya Undang-Undang Nomor 21 Tahun 2008.
\end{abstract}

Kata Kunci: perbankan Islam, sejarah perbankan syariah, Indonesia

Faculty of Law, University of Lancang Kuning Jl. Yos Sudarso Km. 8 Tassel, Pekanbaru, Riau E-mail: andrew.fh.unilak@gmail.com 


\section{Introduction}

According to the five basic principles of Indonesia (Pancasila) and 1945 Constitution (UUD 1945), the purpose of development is the creation of a fair and prosperous society in accordance with economic democracy by developing the balance of economic system. To ensure the ongoing economic democracy, all potentials, initiatives, and creativities of the people must be mobilized and developed within harmless boundaries so that all the powers can be transformed into a force to increase the prosperity of the people. In order to achieve the objective, the implementation of economic development should pay more attention to harmony, balanced growth and national stability.

Banking is anything to do with banks, institutional space, business activities, and ways and processes of the business activities. In simplest terms, the bank is defined as a financial institution which collects funds from the community, channels them back to the community, and provides other services as well. ${ }^{1}$

Based on its tendency in business activities, the type of bank can be distinguished from conventional bank and sharia bank. ${ }^{2}$ Based on Law Number 21 of 2008, conventional bank conducts conventional business activities; while the sharia bank conducts business activities based on sharia principles as they are implemented on fatwa issued by the Central Indonesian Ulama Council. ${ }^{3}$

Referring to the Financial Services Authority in 2017, there are 13 current sharia commercial banks in Indonesia, while sharia business units come from conventional commercial banks. Accordingly, based on the above description, this research focuses on describing how the history and development of sharia banking regulation in national legal system in Indonesia is.

${ }^{1}$ Kasmir, Dasar-dasar Perbankan (Jakarta: Rajawali Pers, 2012), p. 3.

${ }^{2}$ Djoni S. Gazali dan Rachmadi Usman, Hukum Perbankan (Jakarta: Sinar Grafika, 2012), h.151. Abdul Ghofur Anshori, Perbankan Islam di Indonesia (Yogyakarta: Gadjah Mada University Press, 2009). Aziz Budi Setiawan. "Perbankan Syariah: Challenges dan Opportunity Untuk Pengembangan di Indonesia." Jurnal Kordinat 8, no. 1, (2006).

${ }^{3}$ Nurhastuty Wardhany, and Shaista Arshad. "The Role of Shariah Board in Islamic Banks: A Case Study of Malaysia, Indonesia, and Brunei Darussalam.” 2nd Isra Colloquium. 2012. 


\section{Research Method}

This research is a library reasearch. It explores literature and documents relating to the topic discussion. The method used in this research is a normative law research by using the legislation approach. Sources of data used in this study are secondary data, namely data collected from the written rules, scientific journals, and legal literature. The collected data then will be analyzed qualitatively.

\section{Discussion}

Some believe that Islam is a great power which has been hidden, and if it rises it will create enormous power. According to Samuel P. Huntington of Harvard University in his book "The Clash of Civilization", mixing East Asians (Korea, China and Japan) with their economic growth, the Muslims with their large numbers start moving towards 'Islam' as a new identity and power will raise an expectation that is reflected in their belief stated 'Islam is the solution', or 'the raise of Islam'. Similarly, Murad Welfred Houffman, the German Ambassador in Morocco who converted to Islam, in his book "al-Islâm ka Badil (Islam as an Alternative)", says that if we read Adam Smith's theories, David Ricardo, Thomas Malthus, Karl Max, Keynes, and Samuelson, we will realize that we only read the 'history of economic error', not economic history. In fact, each of them believes his theory as the most correct one. ${ }^{4}$

Islam is a comprehensive way of life for every Muslim. Its teachings are universal aimed at the people of the world to achieve the benefit of life in the society, nation and state. In economic terms, Islam encourage people to be spread out on earth looking for God's rewards. ${ }^{5}$

The conventional economy is characterised by its positivistic philosophy based on empirical experience, its foundation, and away

${ }^{4}$ Akhmad Mujahidin, Pemikir Ekonomi Islam (Pekanbaru: BKS PTAIS Riau Press, 2008), p.14-15. See also Hamid Fahmy Zarkasyi. "Liberalisasi Pemikiran Islam: Gerakan Bersama Missionaris, Orientalis dan Kolonialis.” TSAQAFAH 5, no.1, (2009): p. 1-28. Muslim Kara. "Pemikiran Al-Syatibi tentang Maslahah dan Implementasinya dalam Pengembangan Ekonomi Syariah." Jurnal Assets 2, no.2, (2012): p. 173-184.

${ }^{5}$ Akhmad Mujahidin, Pemikir Ekonomi Islam, p.14-15. 
from in God's guidance (secular). In a secular economy, the joy or happiness pursued is merely happiness in the real world only and it's people tend to be very materialistic. Meanwhile, the Islamic economy uses God's guidance of revelation in the form of the Qur'an, sunnah, qiyâs, ijmâa, and ijtihâd. ${ }^{6}$ Thus, in conventional economy, the motives in economic activity is of personal interest, and is solely for personal purposes. Meanwhile, in Islam the driving force is God-interest, that is in order to serve and seek Allah's blessings. ${ }^{7}$

There are several principles of Islamic concepts. First, the transaction should be based on benefits. According to Islam, the owner may use good content by himself or by other parties. Second, money is needed as a means of exchange, because it is not easy to use as a commodity. Ownership of money simply can not provide additional/profit. Furthermore, the transaction must be specific and transparent, because in Islamic sharia, the transaction must be done in good faith, so there can be no gharar. Then, the transaction must be managed properly, because Islam prohibits the existence of maysir (wealth due to the easy way he/she chose). Maysir is the largest in the game zero-sum game, where various parties become part of the other party. This is also called a pure speculator. Finally, the financial institution is the holder of the trust, because in Islam, the financial institution is the party providing the financial services in accordance with the agreement with the owner of the funds. ${ }^{8}$

The history of the first Islamic banking was the establishment of an Islamic bank in Egypt, ${ }^{9}$ the establishment of the Islamic Credit Bank in Cairo in 1963. The first Islamic bank created by private parties

${ }^{6}$ Ataul Huq Pramanik. "Revisiting Islamization of Courses in Economics with Special Emphasis on the Operational Aspect." Journal of Reviews on Global Economics 5, (2016): p. 298-309.

${ }^{7}$ Akhmad Mujahidin, Ekonomi Islam (Jakarta: Rajawali Pers, 2013), p.19-20.

${ }^{8}$ Veithzal Rivai dan Arviyan Arifin, Islamic Banking (Jakarta: Bumi Aksara, 2010), p.143144. See also Yuria Pratiwhi Cleopatra. "Faktor-faktor yang Mempengaruhi Pertumbuhan Proporsi Aset Perbankan Syariah di Indonesia." Jurnal Ekonomi dan Bisnis, Jakarta UI (2008). Hafiez Sofyani, et al. "Islamic Social Reporting Index Sebagai Model Pengukuran Kinerja Sosial Perbankan Syariah (Studi Komparasi Indonesia dan Malaysia)." Jurnal Dinamika Akuntansi 4, no. 1, (2012).

${ }^{9}$ Clement M. Henry, and Rodney Wilson, eds. The Politics of Islamic Finance. (Edinburgh: Edinburgh University Press, 2004). 
was the Dubai Islamic Bank, founded in 1975 by a group of Muslim entrepreneurs from various countries. ${ }^{10}$

The development of sharia banking internationally began with the meeting of the Ministers of Foreign Affairs held by the Organization of Islamic Conference in Pakistan in December 1970. In the event, Egypt proposed the establishment of the International Islamic Bank for Trade, and the establishment of the Federation of Islamic Banks. After discussions among 18 Islam countries, the proposal was finally accepted. In 1975, in the meeting of the Ministers of Finance organized by the Organization of Islamic Conference in Saudi Arabia discussed the establishment of the Islamic Development Bank. ${ }^{11}$

According to the Organization of Islamic Conference, Islamic banks are financial activities that apply laws, rules and procedures based on the sharia principles in the the operational process. ${ }^{12}$ Islamic bank takes a long time to reach its developmnet. One of the causes is a chronic suffering of dualism between economy and sharia. This dualism arises as a result of the inability to describe both economy and sharia in perfect dan whole way. ${ }^{13}$

In Indonesia, for example, as it has been mandated by Pancasila and the 1945 Constitution of the Republic of Indonesia, the goal of development is the creation of a fair and prosperous society based on democracy with an economic system based on fair markets.

In order to realize the goal, the implementation of national economic development, equitable, independent, reliable, fair, and able to compete in the international economic arena. In order to achieve the national goals and can be used in a healthy global competition, it is needed and expanded to support the various potentials that exist in society to support the process of economic acceleration in the effort to reach the goals of national development.

One form of exploring and developing the potential and form of

${ }^{10}$ Abdul Ghofur Anshori, Perbankan Islam di Indonesia, p.25-26.

${ }^{11}$ Abdul Ghofur Anshori, Perbankan Islam di Indonesia, p. 26.

${ }^{12}$ Veithzal Rivai dan Arviyan Arifin, Islamic Banking, p.31.

${ }^{13}$ Muhammad Syafi'i Antonio, "Bisnis dan Perbankan dalam Perspektif Hukum Islam", in Jurnal Al Mawarid 7, (2012): p. 17-25. 
society in the national economy is the development of an economic system based on Islamic values (shari'ah) with its principles in the national legal system. Sharia principles are based on the values of justice, benefit, balance, and universality. ${ }^{14}$ The values used in sharia principles are referred to shariah banking.

The principle of sharia banking is part of Islamic teachings dealing with the economic development. ${ }^{15}$ One of the principles in Islamic economics is the approach in various forms and uses a related system. With the principle of profit sharing, sharia banks can create a healthy and fair investment climate because all parties can share, both profit and potential arise, so that will create an appropriate position between the bank and its customers. In the long term, this will encourage economic equity because the profit is not only enjoyed by the owners of capital alone, but also by capital managers.

The enforcement of Islamic law in Indonesia has been established based on three reasons, namely philosophical reasons, sociological reasons, and juridical reasons. On the philosophical reasons, the teachings of Islam become a way of life, moral ideals, and law among muslims in Indonesia, and this has an important role for the creation of the basic norm of Pancasila. On sociological reasons, the historical development of Indonesian Islamic society shows that the law and legal awareness of Islamic teachings have a sustained level of actuality. While on juridical reasons, as it set forth in Article 24, Article 25, and Article 29 of the 1945 Constitution Islam has a place for the legal validity of juridical law. ${ }^{16}$

The initiative on the establishment of a sharia bank in Indonesia began in 1990. On 18-20 August 1990, the Indonesian Ulama Council held "Banks and Banking Interest Workshop" in Bogor, West Java. The results of the 4th National Assembly of the Indonesian Council of Ulama

${ }^{14}$ Rafiqul Molla, and Md Alam. "Mainstreaming Third-Sector Economics by Adopting Islamic Principles of Entrepreneurship." (2011).

${ }^{15}$ Kamal Naser, Ahmad Jamal, and Khalid Al-Khatib. "Islamic Banking: A Study of Customer Satisfaction and Preferences in Jordan." International Journal of Bank Marketing 17, no. 3, (1999): p. 135-151.

${ }^{16}$ Sumarni, "Kedudukan Hukum Islam dalam Negara Republik Indonesia", in Jurnal AlAdalah 10, no. 4, (2012). M. Erfan Riadi. "Kedudukan Fatwa Ditinjau dari Hukum Islam dan Hukum Positif (Analisis Yuridis Normatif).” Ulumuddin 7, no.1. (2013). 
in Jakarta on 22-25 August 1990 indicated the establishment of a team work to prepare Islamic banking institutions in Indonesia. The result of the team was the establishment of Bank Muamalat Indonesia on November 1, 1991, which officially operated on May 1, 1992. ${ }^{17}$ Later, It was followed by the establishment of a number of Syariah Banks, such as Bank Perkreditan Rakyat Syariah Berkah Amal Sejahtera, Bank Perkreditan Rakyat Syariah Dana Mardhatillah, Bank Perkreditan Rakyat Syariah Amanah Rabaniah di Bandung and Bank Bank Perkreditan Rakyat Syariah Hareukat in Aceh.

The early development of sharia banking in the national banking system was responded quickly by the government. On March 25, 1992, the Law No. 7 of 1992 on Banking was enacted and subsituted the Law No. 14 of 1967 on Banking Principles to accommodate the establishment of sharia banks in Indonesia. ${ }^{18}$

In Article 6, subpart $\mathrm{m}$ and Article 13 subpart c of Law Number 7 of 1992 concerning Commercial Banks and Rural Banks, it was mentioned that the purpose of Syari'ah banking is to provide financing for clients based on profit sharing principles in accordance with the provisions stipulated in government regulations. ${ }^{19}$ This provision, then reinforced by the enactment of Government Regulation No. 72 of 1992 on Banks Through the Profit Sharing Principle, becomes the legal basis for sharia banking in conducting its business activities.

According to Government Regulation Number 72 of 1992, banks based on profit sharing principles are commercial banks or Rural Banks that carry out business activities solely based on the principle of shariabased profit sharing. In determining the benefits to be given to the

${ }^{17}$ Rachmadi Usman, Aspek Hukum Perbankan Syariah di Indonesia (Jakarta: Sinar Grafika, 2012), p.71. See also M. Ali Mansyur. "Aspek Hukum Perbankan Syariah dan Implementasinya di Indonesia." Jurnal Dinamika Hukum 11, (2011): p. 67-75. Yuli Andriansyah. "Kinerja Keuangan Perbankan Syariah di Indonesia dan Kontribusinya bagi Pembangunan Nasional." La_Riba 3, no.2, (2009): p. 181-196.

${ }^{18}$ Andrew Shandy Utama, "Policy Direction on Supervision of Islamic Banking in the National Banking System in Indonesia", in Proceeding of Batusangkar International Conference II, Vol. 1, No. 1, (2017).

${ }^{19}$ Dadan Muttaqin, "Reformasi Regulasi dan Kelembagaan Ekonomi Islam di Indonesia" in Laa Riba 2, No. 1, (Juli 2008). See also M. Ilham F Putuhena, "Politik Hukum Perundangundangan: Mempertegas Reformasi Legislasi yang Progresif." Jurnal Rechts Vinding: Media Pembinaan Hukum Nasional 2, no. 3, (2013): p. 375-395. 
community in connection with the utilization of entrusted community funds to the bank, bank stipulates the benefits to be received in connection with the provision of funds to the public in the form of financing, and stipulates rewards in connection with other business activities commonly carried out by banks with the principle of profit sharing.

The birth of Law Number 10 of 1998 as a change to Law Number 7 of 1992 further strengthened regulations regarding Islamic banking in Indonesia. Article 1 of Law Number 10 of 1998 clearly states that commercial banks and Rural Credit Banks are banks that carry out conventional business activities and/or based on sharia principles. The article also explains the notion of sharia principles, namely the rules of agreement based on Islamic law between banks and other parties for depositing funds and/or financing of business activities, or other activities declared in accordance with sharia, including financing based on the profit sharing principle (mudhârabah), financing based on the principle of equity participation (musyârakah), the principle of buying and selling goods by obtaining profits (murâbahah), and financing capital goods based on the principle of pure rent without choice (ijârah) or by the option of transferring ownership of goods leased from the bank by another party (ijârah wa iqtinâ).

In providing credit and other business activities, both conventional banks and Islamic banks are obliged to follow in ways that do not harm the interests of the bank and the customers who entrust their funds to banks. Given the bank works primarily with public funds that are stored on the bank on the basis of trust, each bank needs to continue to maintain their health and public confidence.

Indonesian people had ever lost confidence in the banking world at the time of the economic crisis in 1998. The economic crisis has resulted in a collapse in the national banking system. The real evidence that was caused was the freezing of 38 bank businesses, including Bank Ciputra, Bank Ganesha, Bank Pesona, Bank Alfa, Bank Aspac, and so on. Furthermore, there were 7 banks taken over by the government, namely Bank RSI, Putera Sukapura Bank, POS Bank, Bank Artha Pratama, Bank Nusa Nasional, Bank Jaya, and Bank IFI. In addition, there were also 4 
government banks, namely Bank Dagang, Exim Bank, Bank Bumi Daya, and Bapindo which were merged to become Bank Mandiri.

However, it turns out that Islamic banks were not affected by the economic crisis that occurred in 1998. At the time of the economic crisis, in fact Bank Muamalat Indonesia, which was the only Islamic public bank in Indonesia, was included in the category of healthy banks because of its Capital Adequacy Ratio with the category "A". This means that Islamic banks showed relatively better performance as compared to conventional banks. ${ }^{20}$

In addition to being a ruin to the national banking system, the economic crisis that occurred in 1998 also became the starting point of the development of Islamic banking in Indonesia. This is because Islamic banks are not affected by the economic crisis. Some conventional banks, both state-owned and private banks, have developed their businesses by establishing Islamic banks, such as Bank Syariah Mandiri, which was established in 1999, Bank Permata Syariah which was established in 2002, Bank Mega Syariah which was established in 2004, Bank Rakyat Indonesia Syariah which was established in 2008, Bank Syariah Bukopin was established in 2008, and so forth. ${ }^{21}$

In respond to the development of significant Islamic banking in the national banking system, then on July 162008 Law Number 21 of 2008 was passed on Sharia Banking as a separate legal basis for Islamic banks in Indonesia. ${ }^{22}$ The Sharia Banking Act Number 21 of 2008, in a juridical philosophy, has fulfilled the demands of a sense of justice and certainty of justice seekers, especially regarding sharia economic business transactions. ${ }^{23}$

${ }^{20}$ Abdul Ghofur Anshori, Perbankan Islam di Indonesia, p.4-5.

${ }^{21}$ Andrew Shandy Utama, "Policy Direction on Supervision of Islamic Banking in the National Banking System in Indonesia".

${ }^{22}$ Andrew Shandy Utama, "Policy Direction on Supervision of Islamic Banking in the National Banking System in Indonesia".

${ }^{23}$ M. Ali Mansyur, "Legal Aspects of Islamic Banking and Its Implementation in Indonesia," in Journal of Dynamics Law 11, (2011). See also Agus Triyanta. "Implementasi Kepatuhan Syariah dalam Perbankan Islam (Syariah)(Studi Perbandingan antara Malaysia dan Indonesia).” Jurnal Hukum Ius Quia Iustum 16, (2009). M. Nur Rianto Al Arif. "Keterkaitan Kebijakan Pemisahan Terhadap Tingkat Efisiensi Pada Industri Perbankan Syariah di Indonesia." Jurnal Keuangan dan Perbankan 19, no. 2, (2015). 
The development of Islamic banking in Indonesia has been going fast and rapid. One of the unique and interesting periods of the long series of developments in Islamic banking in Indonesia is the maturation period of the initial concept and pilot that took place in the decade of the 90s. At that time there was still one Islamic commercial bank, namely Bank Muamalat Indonesia. With its status as the first sharia commercial bank in Indonesia, Bank Muamalat Indonesia became a pilot project and trademark of the rise and massive implementation of Islamic economic law thinking in Indonesia. The decade in which Bank Muamalat Indonesia stood became a momentum that was very much awaited by the people of Indonesia since tens even hundreds of years ago. This period is very strategic because it is a stepping stone to the success or failure of Islamic banking in the next era. ${ }^{24}$ Thus the long stretch of dynamics of Islamic banking in Indonesia cannot be separated from the existence of Bank Muamalat Indonesia.

Based on data from the Financial Services Authority in 2017, currently there are 13 Islamic banks in Indonesia- 21 Islamic banks from conventional banks, and 102 Islamic Banks. This is evidence of the existence and development of significant Islamic banking in the national banking system. That is, Islamic banks are financial institutions that can develop rapidly on the basis of the trust of the Indonesian people who are predominantly Muslim.

In addition to having legal responsibility for the applicable laws and regulations, Islamic banks also have a moral responsibility towards the community and responsibility for worshiping Allah. Islamic banks have moral responsibility towards the community, meaning that the community considers employees who work in Islamic banks to have good character in accordance with Islamic teachings, for example, honest in their work. Islamic banks have the responsibility of worshiping Allah, which means that Islamic banks indirectly preach the Islamic Shari'a in the muamalah field, for example, encouraging people to abandon usury.

${ }^{24}$ Mohamad Nur Yasin. "The arguments Emerging Early Islamic Banking in Indonesia," in Journal de Jure 2, No. 1 (2010). Abul Hassan. "Risk Management Practices of Islamic Banks of Brunei Darussalam." The Journal of Risk Finance 10, no. 1, (2009): p. 23-37. 
The development of Islamic banking in Indonesia is inseparable from the political situation that encompasses its presence and juridical problems and problems with regard to the contact between Islamic law and national law and western law. ${ }^{25}$ Sharia development is influenced by the thoughts and efforts of Islamic scholars and economists, both individually and institutionally, as well as the development and progress of Islamic banking in the international community. ${ }^{26}$ The development of Islamic banks in Indonesia today is running very rapidly. However, the number of banks, the number of offices, and the total number of Islamic bank assets is still very small as compared to conventional banks. ${ }^{27}$

Along with the growth of Islamic banks in Indonesia, it is necessary to have a Sharia Supervisory Board (DPS) in each of these Islamic banks to oversee the operations of Islamic banks in order to keep in line with sharia principles. In additition, a national supervisory board, the National Sharia Council ( DSN), is also required to unite the opinions of the Sharia Supervisory Board, as well as to provide more legal certainty, both for Islamic banks and users of Islamic banking services. Indeed, one of the tasks of the National Sharia Council is to establish fatwas for Islamic banking products and their operations. ${ }^{28}$

\section{Conclusion}

The initiative regarding the establishment of Islamic banks in Indonesia began in 1990 by the Indonesian Ulema Council, which was realized by the establishment of Bank Muamalat Indonesia on November

${ }^{25}$ Muhammad Aswad. "Ekonomi Politik Keuangan Syariah di Indonesia," in DINAMIKA 15, No. 1, (Juli 2015): p. 29-48). Yusuf Wibisono. "Politik Ekonomi UU Perbankan Syariah Peluang dan Tantangan Regulasi Industri Perbankan Syariah." Bisnis \& Birokrasi Journal 16, no. 2, (2011).

${ }^{26}$ Top May Sofyan, "Existence and Law Enforcement of Islamic Banking in Indonesia," Journal of Law Insight 27, No. 2 (2012). Habib Shulton Asnawi. "Hak Asasi Manusia Islam dan Barat (Studi Kritik Hukum Pidana Islam dan Hukuman Mati)." Jurnal Supremasi Hukum 1, no.1, (2012).

${ }^{27}$ Ediana Dian Rae, "Directions Development of Islamic Banking Law," Bulletin of Banking Law and Kebanksentralan 6, No. 1 (2008). Dean F. Amel, and J. Nellie Liang. "The Relationship Between Entry into Banking Markets and Changes in Legal Restrictions on Entry." The Antitrust Bulletin 37, no. 3, (1992): p. 631-649.

${ }^{28}$ Nur Hidayah, "Fatwas National Sharia Council on Islamic Legal Aspects of Islamic Banking in Indonesia," Al-is Journal 10, No. 1 (2011). 
1, 1991. The early development of Islamic banking in the national banking system was responded quickly by the government with the enactment of Law Number 7 In 1992 concerning Banking, which was later amended by Law Number 10 of 1998. Apart from being a ruin to the national banking system, the economic crisis that occurred in 1998 also became the starting point of the development of Islamic banking in Indonesia. Since then some conventional banks began to expand their business by establishing Islamic banks in respond to the development of significant Islamic banking in the national banking system, then on July 162008 Law Number 21 of 2008 was passed on Sharia Banking as a separate legal basis for Islamic banks in Indonesia.

\section{Bibliography}

Amel, Dean F. and J. Nellie Liang. "The Relationship Between Entry into Banking Markets and Changes in Legal Restrictions on Entry." The Antitrust Bulletin 37, no. 3, (1992): 631-649.

Anshori, Abdul Ghofur. Perbankan Islam di Indonesia. Yogyakarta: Gadjah Mada University Press, 2009.

Antonio, Muhammad Syafi'i. "Bisnis dan Perbankan dalam Perspektif Hukum Islam”, in Jurnal Al Mawarid 7, (2012): 17-25.

Andriansyah, Yuli. "Kinerja Keuangan Perbankan Syariah di Indonesia dan Kontribusinya bagi Pembangunan Nasional.” La_Riba 3, no.2, (2009): 181-196.

Al Arif, M. Nur Rianto. "Keterkaitan Kebijakan Pemisahan Terhadap Tingkat Efisiensi Pada Industri Perbankan Syariah di Indonesia." Jurnal Keuangan dan Perbankan 19, no. 2, (2015).

Aswad, Muhammad. "Ekonomi Politik Keuangan Syariah di Indonesia," in DINAMIKA 15, No. 1, (Juli 2015): 29-48).

Asnawi, Habib Shulton. "Hak Asasi Manusia Islam dan Barat (Studi Kritik Hukum Pidana Islam dan Hukuman Mati)." Jurnal Supremasi Hukum 1, no.1, (2012).

Cleopatra, Yuria Pratiwhi. "Faktor-faktor yang Mempengaruhi Pertumbuhan Proporsi Aset Perbankan Syariah di Indonesia." Jurnal Ekonomi dan Bisnis, Jakarta UI (2008). 
Gazali, Djoni S. dan Rachmadi Usman. Hukum Perbankan. Jakarta: Sinar Grafika, 2012.

Hidayah, Nur. "Fatwas National Sharia Council on Islamic Legal Aspects of Islamic Banking in Indonesia," Al-is Journal 10, No. 1 (2011). Henry, Clement M. and Rodney Wilson, eds. The Politics of Islamic Finance. Edinburgh: Edinburgh University Press, 2004.

Hassan, Abul. "Risk Management Practices of Islamic Banks of Brunei Darussalam." The Journal of Risk Finance 10, no. 1, (2009): 23-37.

Kasmir. Dasar-dasar Perbankan. Jakarta: Rajawali Pers, 2012.

Kara, Muslim. "Pemikiran Al-Syatibi tentang Maslahah dan Implementasinya dalam Pengembangan Ekonomi Syariah.” Jurnal Assets 2, no.2, (2012): 173-184.

Mujahidin, Akhmad. Pemikir Ekonomi Islam. Pekanbaru: BKS PTAIS Riau Press, 2008

. Ekonomi Islam. Jakarta: Rajawali Pers, 2013, 19-20.

Molla, Rafiqul, and Md Alam. "Mainstreaming Third-Sector Economics by Adopting Islamic Principles of Entrepreneurship.” (2011).

Mansyur, M. Ali. "Aspek Hukum Perbankan Syariah dan Implementasinya di Indonesia." Jurnal Dinamika Hukum 11, (2011): 67-75.

. "Legal Aspects of Islamic Banking and Its Implementation in Indonesia," in Journal of Dynamics Law 11, (2011).

Muttaqin, Dadan. "Reformasi Regulasi dan Kelembagaan Ekonomi Islam di Indonesia” in Laa Riba 2, No. 1, (Juli 2008).

Naser, Kamal, Ahmad Jamal, and Khalid Al-Khatib. "Islamic Banking: A Study of Customer Satisfaction and Preferences in Jordan." International Journal of Bank Marketing 17, no. 3, (1999): 135-151.

Pramanik, Ataul Huq. "Revisiting Islamization of Courses in Economics with Special Emphasis on the Operational Aspect." Journal of Reviews on Global Economics 5, (2016): 298-309.

Putuhena, M. Ilham F. "Politik Hukum Perundang-undangan: Mempertegas Reformasi Legislasi yang Progresif." Jurnal Rechts Vinding: Media Pembinaan Hukum Nasional 2, no. 3, (2013): 375-395.

Rivai, Veithzal, and Arviyan Arifin. Islamic Banking. Jakarta: Bumi Aksara, 2010 . 
Riadi, M. Erfan. "Kedudukan Fatwa Ditinjau dari Hukum Islam dan Hukum Positif (Analisis Yuridis Normatif).” Ulumuddin 7, no.1. (2013).

Rae, Ediana Dian. "Directions Development of Islamic Banking Law," Bulletin of Banking Law and Kebanksentralan 6, No. 1 (2008).

Setiawan, Aziz Budi. "Perbankan Syariah; Challenges dan Opportunity Untuk Pengembangan di Indonesia." Jurnal Kordinat 8, no. 1, (2006).

Sofyani, Hafiez, et al. "Islamic Social Reporting Index Sebagai Model Pengukuran Kinerja Sosial Perbankan Syariah (Studi Komparasi Indonesia dan Malaysia).” Jurnal Dinamika Akuntansi 4, no. 1, (2012).

Sumarni, "Kedudukan Hukum Islam dalam Negara Republik Indonesia”, in Jurnal Al-'Adalah 10, no. 4, (2012).

Sofyan, Top May. "Existence and Law Enforcement of Islamic Banking in Indonesia," Journal of Law Insight 27, No. 2 (2012).

Triyanta, Agus. "Implementasi Kepatuhan Syariah dalam Perbankan Islam (Syariah)(Studi Perbandingan antara Malaysia dan Indonesia).” Jurnal Hukum Ius Quia Iustum 16, (2009).

Usman, Rachmadi. Aspek Hukum Perbankan Syariah di Indonesia. Jakarta: Sinar Grafika, 2012.

Utama, Andrew Shandy. "Policy Direction on Supervision of Islamic Banking in the National Banking System in Indonesia", in Proceeding of Batusangkar International Conference II, Vol. 1, No. 1, (2017).

Wardhany, Nurhastuty, and Shaista Arshad. "The Role of Shariah Board in Islamic Banks: A Case Study of Malaysia, Indonesia, and Brunei Darussalam." 2nd Isra Colloquium. 2012.

Wibisono, Yusuf. "Politik Ekonomi UU Perbankan Syariah Peluang dan Tantangan Regulasi Industri Perbankan Syariah.” Bisnis \& Birokrasi Journal 16, no. 2, (2011).

Yasin, Mohamad Nur. "The arguments Emerging Early Islamic Banking in Indonesia," in Journal de Jure 2, No. 1 (2010).

Zarkasyi, Hamid Fahmy. "Liberalisasi Pemikiran Islam: Gerakan Bersama Missionaris, Orientalis dan Kolonialis.” TSAQAFAH 5, no.1, (2009): $1-28$. 